\title{
PARAMETER POPULASI DAN SELEKTIVITAS RAJUNGAN (Portunus pelagicus Linnaeus) YANG TERTANGKAP DENGAN BEBERAPA JENIS ALAT TANGKAP DI TELUK JAKARTA
}

\author{
Siti Nuraini, Prihatiningsih, dan Sri Turni Hartati \\ Peneliti pada Balai Riset Perikanan Laut, Muara Baru-Jakarta \\ Teregistrasi I tanggal: 29 Oktober 2008; Diterima setelah perbaikan tanggal: 9 Pebruari 2009; \\ Disetujui terbit tanggal: 14 April 2009
}

\begin{abstract}
ABSTRAK
Rajungan (Portunus pelagicus) merupakan salah satu sumber daya hayati laut yang banyak dimanfaatkan oleh nelayan tradisional. Rajungan di Teluk Jakarta selain sebagai sasaran penangkapan pada bubu dan jaring rajungan, juga tertangkap dengan sero, bagan, dan jaring arad. Penelitian ini dilakukan pada tahun 2006 dengan tujuan untuk memperoleh informasi parameter stok dan selektivitas beberapa alat tangkap rajungan. Hasil pengamatan menunjukkan bahwa rajungan yang tertangkap mempunyai lebar karapas $4,16-11,9 \mathrm{~cm}$ dan bobot antara 5,1-113 g. Rajungan pertama kali tertangkap ( $\left.\mathrm{LC}_{50 \%}\right)$ pada sero, bagan, bubu, jaring rajungan, dan jaring arad pada ukuran lebar karapas 6,$3 ; 7,3 ; 8,54 ; 8,96$; dan $8,69 \mathrm{~cm}$. Hampir semua (>95\%) rajungan yang tertangkap dengan sero dan bagan merupakan rajungan kecil. Rajungan dewasa yang tertangkap pada jaring arad, bubu, dan jaring rajungan diperoleh 41,66 , dan $68 \%$. Perbandingan kelamin jantan terhadap betina tidak sama pada alat tangkap yang digunakan. Hubungan antara lebar karapas dan panjang karapas pada sero, bagan, dan bubu rajungan mengikuti persamaan $C W=0,4446 C L+0,1892(r=0,9)$. $C W=0,4314 C L+0,3475(r=0,84)$, dan $C W=0,4718 C L+0,1843(r=0,83)$.
\end{abstract}

KATAKUNCl: rajungan, nisbah kelamin, selektivitas, sero, bagan, bubu, jaring arad, jaring rajungan

ABSTRACT: Population parameters and selectivity of swimming crab (Portunus pelagicus Linnaeus) on several fishing gears in Jakarta Bay. By: Siti Nuraini, Prihatiningsih, and Sri Turni Hartati

Swimming crab, Portunus pelagicus is one of marine organism resources, intensively exploited by artisanal fisheries. This crabis targeted species of trap and monofilament gill net and also as by catch of guiding barrier trap, fixed lift net, and monofilament gill net. The study was conducted in Jakarta Bay in 2006. The objectives of this study are to determine population parameters and selectivity of swimming crab on several fishing gears used in Jakarta Bay. The swimming crabs were caught between $4.16-11.9 \mathrm{~cm}$ in carapace width and between $5.1-113 \mathrm{~g}$ in weight. The first captured ( $\left.\mathrm{LC}_{50 \%}\right)$ of swimming crab caught by guiding barrier trap, fixed lift net, collapsible trap, beach seine, and monofilarment gill net were 6.3, 7.3, 8.54, 8.69, and for $8.96 \mathrm{~cm}$, respectively. Guiding barrier trap and fixed lift net caught small crab for more than $95 \%$. Large crab was caught by beach seine, collapsible trap, and monofilament gill net for crab were 41,66 , dan $68 \%$ of the total catch. The sex ratio between male and female diferred among the gears used. The relationship between $C W$ and $C L$ of guiding barrier trap, fixed lifnet, bagan, and trap follows the equation $C W=0.4446 C L+0.1892(r=0.9)$, $C W=0.4314 C L+0.3475(r=0.84)$, and $C W=0.4718 C L+0.1843(r=0.83)$.

KEYWORDS: $\quad$ selectivity, sex ratio, crab, guiding barrier trap, fixed lift net, collapsible trap, seine net

\section{PENDAHULUAN}

Rajungan (Portunus pelagicus Linnaeus) hidup di perairan tropis dan sub tropis pada kawasan IndoWest Pacific, yaitu perairan Samudera Hindia meliputi Indonesia, India-Laut Merah, perairan barat, selatan dan utara Australia kecuali Tasmania, Samudera Pasifik meliputi Fiji, Solomon, Ryukyu (Potter et al., 1983). Rajungan dijumpai pada perairan pantai sampai dengan continental shelf pada ekosistem estuaria yang berlumpur, pasir, atau padang lamun sampai kedalaman 50 m (Kailola et al., 1993). Sebagai komoditas yang mempunyai nilai ekonomis penting rajungan telah diekspor dalam bentuk beku dan daging olahan.

Penangkapan rajungan di perairan Teluk, Jakarta dilakukan oleh nelayan tradisional dengan beberapa jenis alat tangkap. Sebagai alat tangkap utamanya digunakan bubu lipat dan jaring rajungan (Karsono et al., 2006). Rajungan juga tertangkap dengan sero, bagan tancap, dan jaring arad sebagai hasil 
sampingan. Untuk kepentingan pendugaan populasi ikan, data yang seringkali digunakan yaitu data tangkapan dan upaya penangkapan. Permasalahannya pada perikanan rajungan yang multigears kegiatan pencatatan data tersebut sulit dimonitor. Data statistik hasil tangkapan rajungan belum tercatat pada semua instansi terkait yaitu di Kabupaten Bekasi dan Kabupaten Tangerang di mana hasil rajungan dari Teluk Jakarta didaratkan.

Produksi rajungan dari DKI Jakarta berfluktuasi selama tahun 2003-2007. Pada tahun 2003 produksi rajungan tercatat 308 ton. Produksi rajungan terendah terjadi tahun 2004 yaitu 32 ton (Anonimous, 2007). Produksi tertinggi tercatat 723 ton tahun 2006 dan turun 135 ton tahun 2007. Nilai ekspor rajungan pada tahun 2006 US $\$ 221,262$ (87 ton) (Anonimous, 2007). Penurunan produksi juga terlihat di beberapa daerah misalnya di perairan Bondet, Kabupaten Cirebon sejak tahun 1997 yaitu $60 \%$, di perairan Pulau Pari, Kepulauan Seribu pada periode tahun 1991-1992 sudah sulit dijumpai larva rajungan, yang dikatakan melimpah tahun 1975.

Penangkapan rajungan yang sangat intensif dapat membahayakan kelestarian sumber dayanya. Oleh karena itu, diperlukan strategi pengelolaan yang optimal supaya produksinya tetap meningkat. Untuk pengelolaan sumber daya ikan yang optimal hendaknya analisis didasarkan pada data dan informasi tentang aspek dinamika populasi. Pada kajian estimasi stok, alat tangkap yang digunakan sesuai dan dapat mewakili populasi yang ada. Tulisan ini membahas beberapa aspek dinamika populasi rajungan dan mengkaji selektivitas hasil tangkapan dan komposisinya pada beberapa alat tangkap, struktur ukuran, ukuran pertama kali tertangkap (LC), dan nisbah kelamin. Hasil penelitian ini diharapkan dapat digunakan sebagai bahan masukan untuk tujuan pengelolaan dan dasar bagi penelitian sumber daya rajungan selanjutnya.

\section{BAHAN DAN METODE}

\section{Pengumpulan Data}

Pengumpulan data tangkapan rajungan, swimming crab, Portunus pelagicus dilaksanakan pada bulan Maret, Mei, Agustus, Oktober, dan Desember 2006. Data tangkapan dan ukuran rajungan diperoleh dari hasil tangkapan sero (guiding barrier trap), bagan tancap (fixed lift net), bubu rajungan (collapsible trap), jaring arad (seine net), dan jaring rajungan (monofilament gillnet). Pengamatan dilakukan di tempat pendaratan ikan di Muara Kamal, Tangerang, Kali Adem, Ancol, dan Cilincing, Jakarta Utara. Data tersebut terdiri atas 1) aspek biologi meliputi pengukuran panjang individu (panjang karapas dan lebar karapas), bobot individu rajungan, jenis kelamin dan 2) aspek produksi perikanan meliputi hasil tangkapan, alat tangkap, dan daerah penangkapan ikan.

\section{Analisis Data}

\section{Panjang-Lebar Karapas}

Rajungan diukur panjang karapas (carapas length) dan lebar (carapas width) dengan ketelitian $0,1 \mathrm{~cm}$ dan ditimbang bobotnya dengan ketelitian $1 \mathrm{~g}$.

\section{Pendugaan ukuran pertama kali tertangkap (LC)}

Pendugaan ukuran rajungan pertama kali tertangkap dilakukan dengan membuat grafik hubungan antara lebar karapas (sumbu $X$ ) dengan jumlah ikan yang dikatakan dengan persentase kumulatif (sumbu $Y$ ) sehingga diperoleh kurva berbentuk S. Nilai length at first capture yaitu panjang $50 \%$ pertama kali tertangkap dihitung dengan persamaan sebagai berikut (Jones, 1976 dalam Sparre \& Venema, 1992):

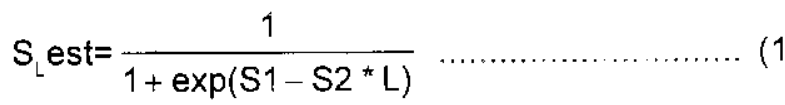

$$
\begin{aligned}
& \operatorname{Ln}\left[\frac{1}{S L}-1\right]=S 1-S 2 * L \\
& \mathrm{~L} 50 \%=\frac{\mathrm{S} 1}{\mathrm{~S} 2} \\
& \text { di mana: } \\
& \mathrm{SL} \quad=\text { kurva logistik (selektivitas alat } \\
& \text { sebagai fungsi panjang) } \\
& \text { SI \& S2 = konstanta pada rumus kurva logistik } \\
& \text { S1 }=a \\
& \text { S2 }=b
\end{aligned}
$$

Perairan Teluk Jakarta merupakan perairan yang terbuka dan sangat dipengaruhi oleh Laut Jawa dan merupakan perairan estuaria di mana bermuara Sungai Ciliwung dan Citandui. Sementara itu, daerah penangkapan jaring rajungan yaitu perairan sekitar Pulau Onrust, Pualu Bidadari, Pulau Kahyangan sampai ke Untung Jawa. Lokasi penangkapan 
rajungan dengan sero, bagan, bubu lipat, jaring arad, dan jaring rajungan meliputi muara sungai di Teluk Jakarta, kawasan pantai yang dangkal sekitar Cilincing, Muara Baru, Ancol, Kamal, dan Tanjung Priuk, Pulau Air, Pulai Onrust, Pulau Cipir, Pulau Bidadari sampai dengan ke perairan sekitar Pulau Untung Jawa (Gambar 1 dan Tabel 1).

\section{HASIL DAN BAHASAN}

\section{Alat Tangkap dan Musim Penangkapan}

Berdasarkan pada hasil pengamatan di Teluk Jakarta, beberapa jenis alat tangkap yang menangkap rajungan yaitu sero, bagan, bubu lipat, jaring arad, dan jaring rajungan. Bubu lipat dan jaring rajungan merupakan alat tangkap dengan sasaran rajungan. Rajungan juga merupakan hasil sampingan dari jenis alat tangkap lain. Penangkapan rajungan dengan bubu dan jaring rajungan dilakukan sepanjang tahun dengan puncak penangkapan pada bulan Juni dan Juli. Sero, bagan, dan jaring arad menangkap ikan sepanjang tahun. Pada musim barat penangkapan hanya dilakukan pada cuaca yang baik. Ringkasan spesifikasi alat tangkap yang digunakan oleh nelayan di Teluk Jakarta (Tabel 2).

\section{Hasil dan Komposisi Tangkapan}

Hasil tangkapan sero, bagan tancap, bubu lipat, jaring arad, dan jaring rajungan di perairan Teluk Jakarta dapat dilihat pada Gambar 2. Hasil tangkapan sero pada bulan Maret-April 2006 yaitu 10-120 kg. Rajungan yang tertangkap 2-30 kg per trip atau 20$25 \%$ dari.tangkapan total. Hasil tangkapan bagan dari pemantauan bulan Mei 2006 diperoleh rata-rata tangkapan 48 kg per trip dan bulan Oktober 616 kg per trip. Rajungan yang tertangkap diperoleh kurang dari $5 \%$ dari tangkapan total. Hasil tangkapan rajungan dengan bubu lipat, jaring arad, dan jaring

Tabel 1. Lokasi penangkapan rajungan dengan berbagai alat tangkap

Table 1. Fishing location of swimming crab using various gears

\begin{tabular}{|c|c|c|c|}
\hline \multirow{2}{*}{ No. } & \multirow{2}{*}{$\begin{array}{l}\text { Alat tangkap/ } \\
\text { Fishing gear }\end{array}$} & \multicolumn{2}{|c|}{ Posisi/Position } \\
\hline & & Lintang/Altitude & Bujur/Latitude \\
\hline 1. & Sero & 05 93'37" S-06 09'01" S & 106 43'0.70" E-107 03'0.70" E \\
\hline 2. & Bagan tancap & 06 02'04" S-06 03'10.7" S & 106 43'0.70" E-107 03'0.70" E \\
\hline 3. & Bubu rajungan & 05 95'37" S-06 07'01" S & 106 01'68.0.3" E-106 98'40" E \\
\hline 4. & Jaring rajungan & 05 87’30" S-06 0’01" S & 106 01'68.0.3" E-106 85'40" E \\
\hline 5. & Jaring arad & 05 98'37" S-06 07'11.9" S & $1068^{\prime} 50.8^{\prime \prime}$ E-106 93'50.8" E \\
\hline
\end{tabular}

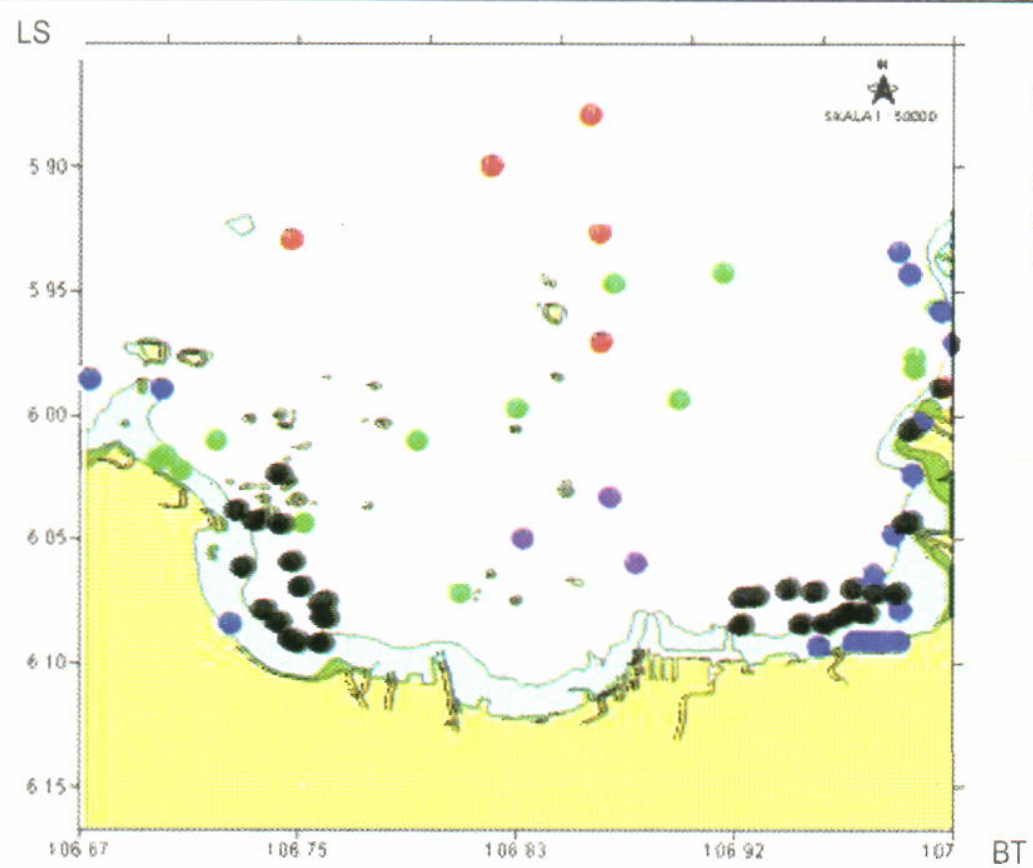

Gambar 1. Daerah penangkapan rajungan di perairan Teluk Jakarta dengan menggunakan sero, bagan, bubu, jaring arad, dan jaring rajungan.

Figure 1. Fishing ground of swimming crab using guiding barrier trap, fixed lift net, collapsible trap, beach seine, and monofilament gill net for crab in Jakarta Bay. 
Tabel2. Spesifikasi beberapa alat tangkap (mata jaring, ukuran alat tangkap, tonase kapal, dan lama trip)

Table 2. Characteristic of fishing gears (mesh size, size of gear, gross ton, and trip duration)

\begin{tabular}{|c|c|c|c|c|}
\hline $\begin{array}{l}\text { Alat tangkap/ } \\
\text { Fishing gear }\end{array}$ & $\begin{array}{l}\text { Bahan dan ukuran jaring/ } \\
\text { Material and mesh size }\end{array}$ & $\begin{array}{l}\text { Ukuran alat tangkap/ } \\
\text { Gear size }\end{array}$ & GT & $\begin{array}{l}\text { Lamanya trip/ } \\
\text { Trip duration }\end{array}$ \\
\hline Sero & $\begin{array}{l}\text { Waring } \varnothing 3 \mathrm{~mm} \text {, tali ris atas PE } \varnothing 3 \\
\mathrm{~mm}\end{array}$ & $\begin{array}{l}\text { P } 100 \mathrm{~m} \text {, dan keliling } \\
50 \mathrm{~m}\end{array}$ & $11 ; 14 ; 18 ; 26$ & Daily \\
\hline Bagan tancap & Monofilament 2-5 mm & $9-10 \times 9-10 m$ & & Daily \\
\hline Bubu lipat & $\begin{array}{l}\text { PE.D6.\#1.25" \& wire seng -krom Ø } 4 \\
\text { mm }\end{array}$ & $20 \times 30 \mathrm{~cm}$ & $20 \& 25$ & Daily \\
\hline Jaring arad & Kantong dan sayap dari waring $0,3 \mathrm{~cm}$ & $120-140 \times 5 m \& 2-3 m$ & 5 & Daily \\
\hline Jaring rajungan & Monofilament 1 lapis: 2,5 inci & $100 \times 8 \times 2 m$ & $15 \& 18$ & 1-3 day \\
\hline
\end{tabular}
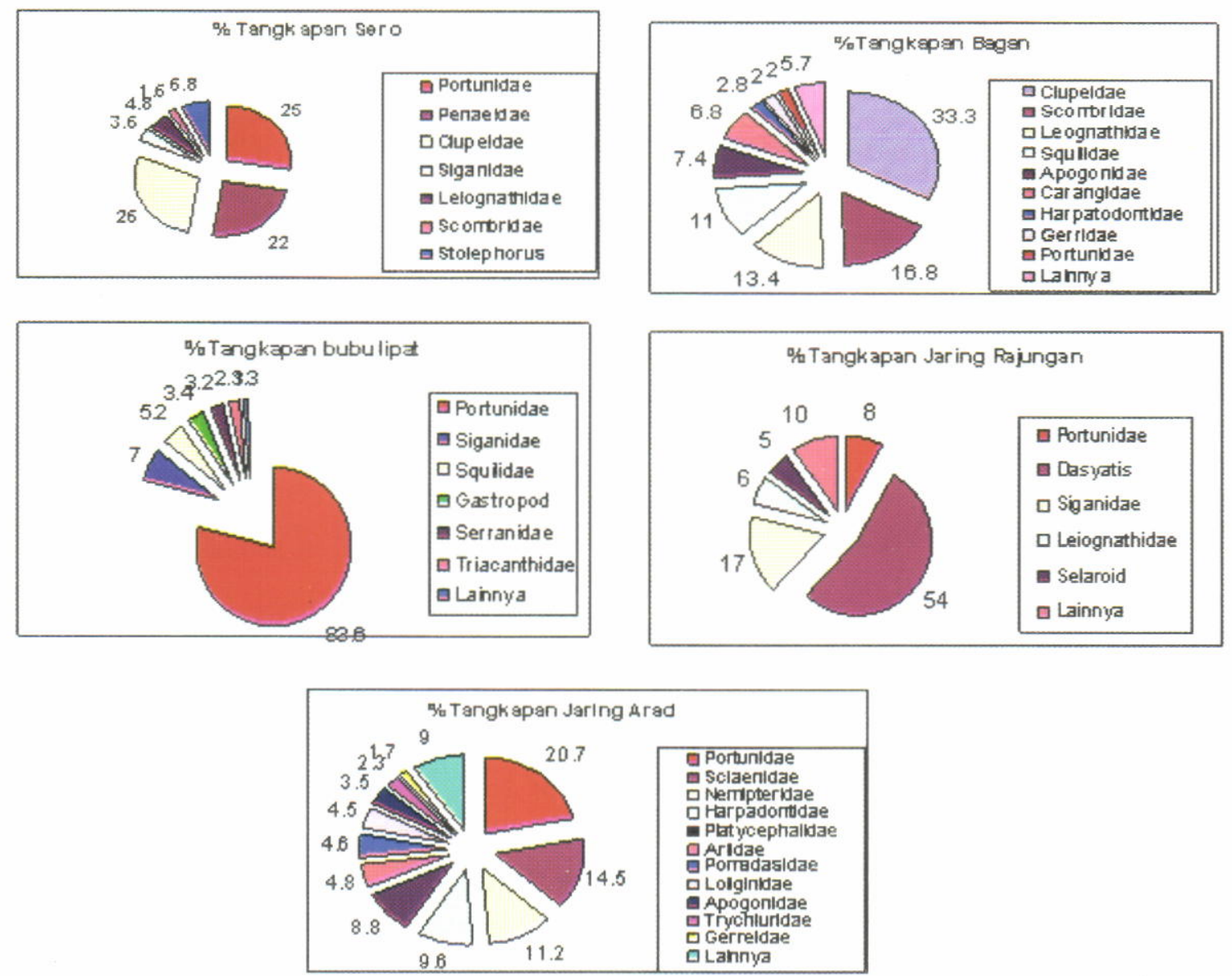

Gambar 2. Komposisi jenis tangkapan sero, bubu lipat, bagan tancap, jaring arad, dan jaring rajungan di Teluk Jakarta, tahun 2006.

Figure 2. Catch composition of guiding barrier trap, collapsible trap, station lift net, beach seine, and monofilament gillnet in Jakarta Bay, in 2006.

rajungan masing masing berkisar antara 5-7; 2,5-7; dan 5-11,3 kg per trip.

Jenis ikan hasil tangkapan sero antara lain rajungan, kepiting (Crab), udang krosok (Metapenaeus spp.), teri, (Stolephorus spp.), petek (Leiognathus bindus), selar kuning (Selaroides leptolepis), tenggiri
(Scomberomerous sp.), kembung (Rastrelliger brachysoma), dan ikan rucah. Hasil tangkapan bubu lipat terdiri atas ikan pari (Plesiobatis sp.) dan ikan campuran. Ikan campuran terdiri atas 11 jenis. Hasil tangkapan jaring arad didominansi ikan kurisi (Nemipterus spp.) 14\% dan gulamah (Johnius sp.) $14,5 \%$. 


\section{Perbandingan Jenis Kelamin (Nisbah Kelamin)}

Hasil pengamatan terhadap seks rasio rajungan di perairan Teluk Jakarta menunjukkan adanya perbedaan pada masing-masing alat tangkap (Gambar 3). Sero menangkap rajungan jantan lebih banyak dari betina $(1: 0,7)$. Bagan menangkap rajungan jantan lebih kecil dari betina (M:F=1:1,4). Pada bubu lipat diperoleh rajungan jantan lebih kecil dari betina ( $M: F=1: 1,3$ ); pada jaring arad hasil tangkapan jantan lebih banyak dari betina ( $M: F=2: 1$ ) dan sebaliknya pada jaring rajungan diperoleh jenis jantan separuh dari jenis betina ( $M: F=1: 2)$. Terjadinya perbedaan seks rasio rajungan di perairan Teluk Jakarta diduga karena lokasi penangkapan dan perbedaan pilihan (preference) habitat antara jantan dan betina yang terjadi beberapa kali dalam setahun (Meager dalam Sumpton et al., 1994).

Pada waktu memijah rajungan betina dewasa bermigrasi ke perairan estuaria menuju perairan yang lebih dangkal dan akan kembali ke estuaria sesudah memijah (Bellchambers \& Lestang, 2005). Migrasi rajungan betina ke perairan yang dangkal dan berpasir untuk meletakkan telornya untuk keberhasilan pada proses pemijahan (Potter et al., 1983; Cambell dalam Kangas, 2000). Penurunan jumlah rajungan betina dewasa $(>8,6 \mathrm{~cm} \mathrm{CW})$ pada hasil tangkapan mengakibatkan dominansi rajungan jantan pada hasil tangkapan.

Nisbah kelamin rajungan jantan dan betina menunjukkan perbedaan pada beberapa alat tangkap yang digunakan. Hasil tangkapan rajungan dengan traw/dan pukat pántai hampir sama jumlahnya (Potter et al., 1983). Hasil tangkapan dengan bubu di kawasan estuaria di Leschenault, Australia diperoleh rajungan jantan dan betina 3-3,8:1 (Kangas, 2000; Bellchambers \& De Lesiang, 2005). Kecenderungan rajungan jantan tertangkap lebih besar dari betina diduga disebabkan oleh perilaku rajungan jantan yang lebih agresif (Sumpton \& Smith dalam Bellchambers \& De Leslang, 2005), sehingga nisbah kelamin rajungan pada bubu menggambarkan perilaku rajungan.
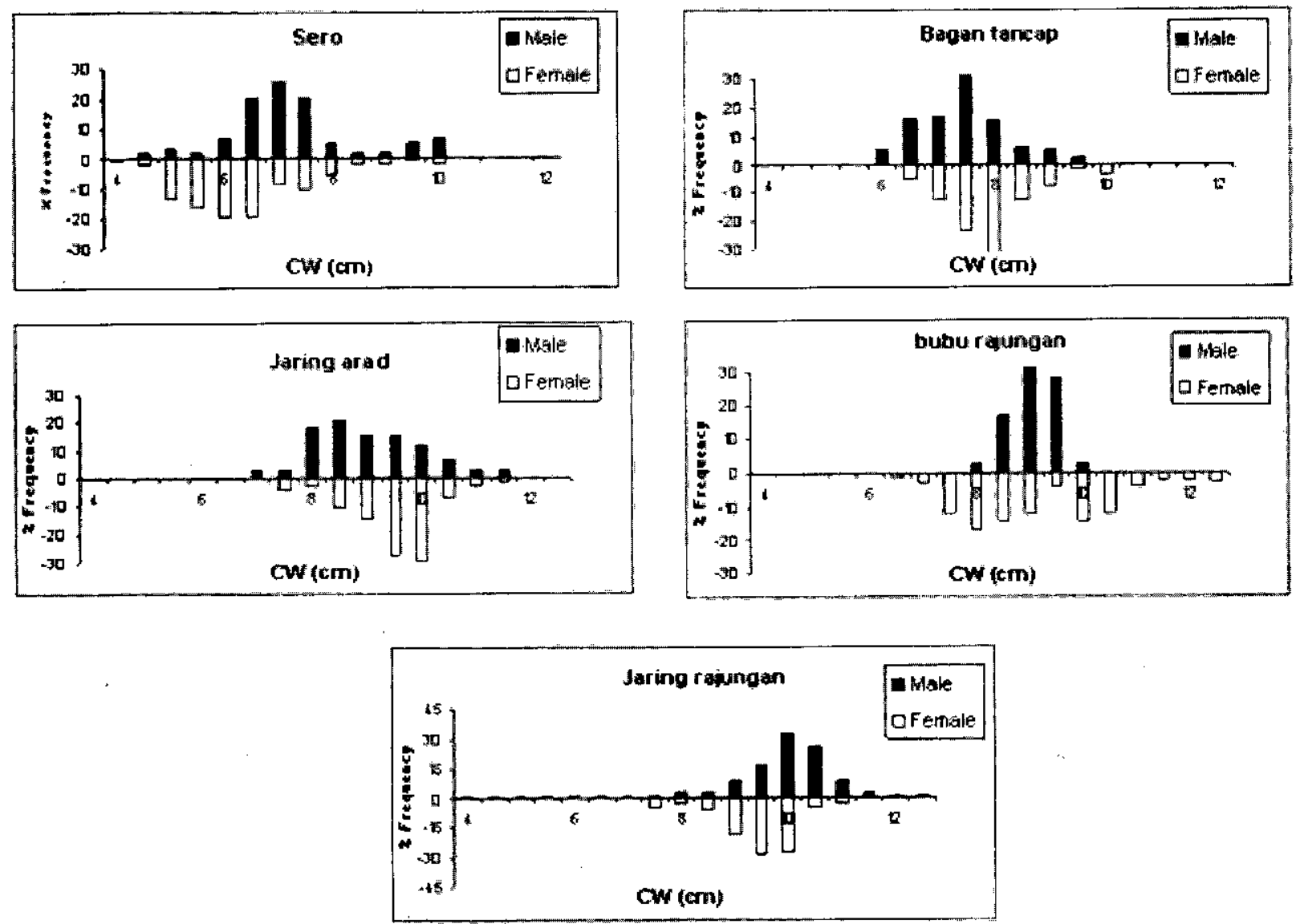

Gambar 3. Perbandingan jenis bkelamin rajungan dengan sero, bagan tancap, bubu lipat, jaring arad, dan jaring rajungan di perairan Teluk Jakarta.

Figure 3. Sex ratios of Portunus pelagicus Linnaeus by five different gear types; guiding barrier trap, fixed lift net, collapsible trap, beach seine, and monofilament gillnet in Jakarta Bay. 
Di perairan Teluk Jakarta, rajungan betina dewasa ( $L>L m$ ) yang tertangkap dengan sero dan bagan tancap diperkirakan jumlahnya $<5 \%$ dari total tangkapan. Rajungan dewasa yang tertangkap dengan jaring arad, jaring rajungan dan bubu masing-masing 41,68 , dan $66 \%$ dari jumlah rajungan yang tertangkap. Rendahnya rajungan betina dewasa diduga karena lokasi penangkapan sero dan bagan tancap terletak pada kawasan pantai yang dipengaruhi muara sungai. Potter et al. (1983) mengatakan bahwa kawasan estuaria merupakan daerah asuhan rajungan, artinya rajungan yang tertangkap di perairan ini merupakan rajungan muda yang berukuran kecil.

\section{Sebaran Ukuran}

Hampir semua alat tangkap bersifat selektif terhadap spesies sasaran (King, 1995). Pukat ikan mempunyai peluang lebih besar untuk menangkap ikan yang berukuran kecil dari pada ikan besar karena berenang lebih cepat dan dapat meloloskan diri dari pukat. Gillnet menangkap ikan kecil dan besar sesuai dengan mata jaring yang digunakan. Pancing menangkap ikan kecil dan sangat besar tergantung dari mata pancing dan umpan yang digunakan. Bellchambers \& De Lestang (2005) mengatakan bahwa dengan menggunakan alat tangkap seine net (payang) dan trawl (pukat ikan) diperoleh sebaran ukuran rajungan yang lebih besar daripada dengan alat tangkap bubu. Penggunaan mata jaring yang berukuran kecil menjadikan hasil tangkapan memiliki sebaran yang lebih luas.
Rajungan yang tertangkap di Teluk Jakarta mempunyai lebar karapas berkisar 4,16-11,9 cm dan bobot berkisar 5,1-113 g. Rajungan yang tertangkap dengan sero (lebar karapas $6,8 \mathrm{~cm}$ ) < bagan tancap (lebar karapas 7,2 cm); pada bubu diperoleh lebar karapas dengan rata-rata $8,7 \mathrm{~cm}$ dan dengan jaring rajungan yang terbesar $(9,3 \mathrm{~cm})$. Rata-rata bobot rajungan yang tertangkap dengan sero, bagan tancap. bubu lipat, dan jaring arad, masing-masing 21,3; 24,6; 34,$8 ; 45 \mathrm{~g}$; dan jaring rajungan $56,2 \mathrm{~g}$ (Tabel 3 ).

Kisaran lebar karapas rajungan berbeda pada setiap alat tangkap. Rajungan yang tertangkap sero dan jaring arad dengan lebar karapas berkisar 4,2-10 $\mathrm{cm}$ dan memiliki kisaran yang paling tinggi 5,3-5,8 $\mathrm{cm}$. Kisaran lebar karapas tinggi diduga karena penggunaan jaring dengan mata jaring yang kecil. Bagan menangkap rajungan dengan lebar karapas pada 5,5-9.4cm dan panjang karapas $P K 3,8-3,9 \mathrm{~cm}$. Pada rajungan yang tertangkap dengan jaring rajungan dengan kisaran lebar karapas 7,2-11,1 cm.

Sebaran frekuensi lebar karapas rajungan jantan $(1,6 \mathrm{~cm})$ yang tertangkap dengan bubu lebih kecil dari pada betina $(4 \mathrm{~cm})$. Keadaan ini mengindikasikan bahwa rajungan jantan yang lebih kecil tidak tertangkap dengan bubu. Hasil pengamatan Potter et al. (1991) mengatakan bahwa rajungan jantan sangat agresif (antagonistic social interactions) terhadap rajungan yang lebih kecil. Dengan hadirnya rajungan jantan besar pada bubu, maka rajungan kecil tidak akan memasuki dan terperangkap dalam tangkapan

Tabel 3. Sebaran ukuran lebar karapas dan bobot $(\mathrm{g})$ dari rajungan jantan dan betina yang tertangkap dengan sero, bagan tancap, jaring arad, bubu, dan jaring rajungan di Teluk Jakarta

Table 3. Size distribution of swimming crab carapace width and weight $(g)$ of male and female caught using guiding barrier trap, fixed lift net, beach seine, collapsible trap, and monofilament gillnet for crab in Jakarta Bay

\begin{tabular}{|c|c|c|c|c|c|c|c|c|}
\hline \multirow{2}{*}{$\begin{array}{l}\text { Alat tangkap/ } \\
\text { Fishing gear }\end{array}$} & \multirow{2}{*}{$\begin{array}{c}\text { No. } \\
\text { sample }\end{array}$} & \multicolumn{3}{|c|}{$\begin{array}{c}\text { Lebar karapaks/ } \\
\text { Carapace width }(\mathrm{cm})\end{array}$} & \multirow[b]{2}{*}{$\begin{array}{c}\text { No. } \\
\text { Sample }\end{array}$} & \multicolumn{3}{|c|}{$\begin{array}{c}\text { Berat/ } \\
\text { Weight (g) }\end{array}$} \\
\hline & & $\begin{array}{c}\text { Rerata/ } \\
\text { Mean }\end{array}$ & $\begin{array}{c}\text { Simpangan } \\
\text { baku/ } \\
S D \\
\end{array}$ & $\begin{array}{l}\text { Ukuran/ } \\
\text { Size } \\
\text { range }\end{array}$ & & $\begin{array}{c}\text { Rerata/ } \\
\text { Mean }\end{array}$ & $\begin{array}{c}\text { Simpangan } \\
\text { bakul } \\
\text { SD }\end{array}$ & $\begin{array}{l}\text { Ukuran/ } \\
\text { Size range }\end{array}$ \\
\hline \multicolumn{9}{|l|}{ Male } \\
\hline Sero & 70 & 6,8 & 1,1928 & 5,6 & 74 & 21,3 & 13,3914 & 58,7 \\
\hline Bagan & 121 & 7,2 & 0,77 & 3,8 & 129 & 24,6 & 8,5687 & 53,2 \\
\hline bubu lipat & 39 & 8,7 & 0,4331 & 1,6 & 43 & 45 & 7,5847 & 33,6 \\
\hline Jaring arad & 33 & 8,3 & 1,1102 & 5,3 & 50 & 56,2 & 13,5624 & 65,8 \\
\hline $\begin{array}{l}\text { Jaring rajungan } \\
\text { Female }\end{array}$ & 46 & 9,3 & 0,6981 & 3,7 & 37 & 34,8 & 17,7192 & 103,5 \\
\hline Sero & 120 & 6,6 & 1,1137 & 5,8 & 85 & 19,4 & 10,4412 & 60,4 \\
\hline Bagan & 155 & 7,3 & 0,7954 & 3,9 & 112 & 24,8 & 6,8712 & 41,9 \\
\hline Bubu lipat & 90 & 8,7 & 0,7874 & 4 & 51 & 40,4 & 11,5251 & 47,7 \\
\hline Jaring arad & 100 & 8,7 & 1,1922 & 5,7 & 23 & 49,9 & 17,3228 & 58,1 \\
\hline Jaring rajungan & 69 & 9,3 & 0,7958 & 3,9 & 67 & 44,6 & 18,5477 & 87,2 \\
\hline
\end{tabular}


bubu. Pada penelitiannya dengan menggunakan trawl dan sero rajungan kecil ikut tertangkap.

\section{Panjang Pertama Kali Tertangkap}

Ukuran panjang ikan pertama kali tertangkap (LC) diperoleh dengan cara memplotkan panjang total ikan berdasarkan pada kelompok panjang dengan jumlah ikan yang dikatakan dalarn persentase kumulatif. Pendugaan ukuran pertama kali tertangkap digunakan sebagai salah satu acuan dalam menentukan upaya dari pengelolaan sumber daya perikanan berdasarkan pada informasi ukuran ikan yang tertangkap dengan alat tangkap tertentu. Rata-rata ukuran rajungan yang tertangkap (Lc) digambarkan oleh $50 \%$ sebaran frekuensi kumulatif ukuran rajungan yang tertangkap. Pada studi ini kita mengkaji $\mathrm{LC}_{50 \%}$ rajungan karena beberapa jenis alat tangkap yang digunakan di perairan ini.

Dengan interpolasi hasil tangkapan secara kumulatif dan ukuran rajungan dapat diketahui selektivitas beberapa jenis alat tangkap (Gambar 4). Dapat disimpulkan bahwa rajungan yang berukuran besar lebih mudah tertangkap dengan bubu, jaring arad, jaring rajungan dan rajungan kecil dengan bagan dan sero. Bagan mempunyai kecenderungan untuk menangkap rajungan yang lebih besar dari pada sero, meskipun diduga bahwa kedua alat ini menangkap rajungan dari kohort yang sama.

Berdasarkan pada hasil pengamatan dengan alat tangkap sero diperoleh $\mathrm{Lc}=6,30 \mathrm{~cm}$, dengan bagan $\mathrm{Lc}_{50 \%}=7,3 \mathrm{~cm}$, bubu lipat $\mathrm{Lc}_{50 \%}=8,54 \mathrm{~cm}$, dengan jaring rajungan diperoleh nilai terbesar dengan $\mathrm{LC}_{50 \%}=$ $8,96 \mathrm{~cm}$ dan jaring arad dengan $\mathrm{LC}_{50 \%}=8,69 \mathrm{~cm}$. Berdasarkan pada hasil kajian Potter et al. (1998), rajungan betina matang telor dijumpai pada lebar karapas 8,9 dan 9,6 cm. Rajungan jantan dewasa di India dijumpai dengan lebar karapas pada 8,5-9,0 cm dan jenis betina pada $8,0-9,0 \mathrm{~cm}$ (Sukamaran \& Neelakantan, 1996).

Selektivitas alat adalah fungsi ukuran ikan dan mata jaring yang digunakan dan lamanya perendaman bubu dan sero di dalam air. Sero dan bagan mempunyai selektivitas yang tinggi terhadap rajungan muda. Hanya 1-2\% rajungan memiliki LK>Lm. Rajungan muda hasil tangkapan bubu, jaring arad, dan jaring rajungan sekitar $50-60 \%$ dari total tangkapan. Hasil tangkapan sero dan bagan yang sebagian besar rajungan kecil diduga karena lokasi penangkapannya pada daerah asuhan. Dengan menerapkan batas minimal rajungan yang boleh ditangkap (legal size) misalnya yang digunakan di Australia pada lebar karapas $12,6 \mathrm{~cm}$, maka akan berdampak pada perubahan $\mathrm{Lc}_{50 \%}$ menjadi lebih besar dan kelestarian sumber daya rajungan akan lebih terjaga.

\section{Hubungan antara Panjang Karapas dan Lebar Karapas}

Salah satu hal dalam mempelajari populasi ikan yaitu melalui studi morfometrik dengan cara membandingkan ukuran-ukuran tertentu dari satu tempat ke tempat yang lain. Ukuran panjang karapas (carapace length) dan lebar karapas (carapace width) yang ditangkap di Teluk Jakarta dapat dijadikan pembanding bagi jenis rajungan yang sama dari perairan lain. Informasi hubungan antara panjang dan lebar karapas rajungan dari perairan lain sangat terbatas. Dari 480 contoh rajungan diperoleh hubungan antara masing-masing panjang dan lebar karapas (Tabel 4).

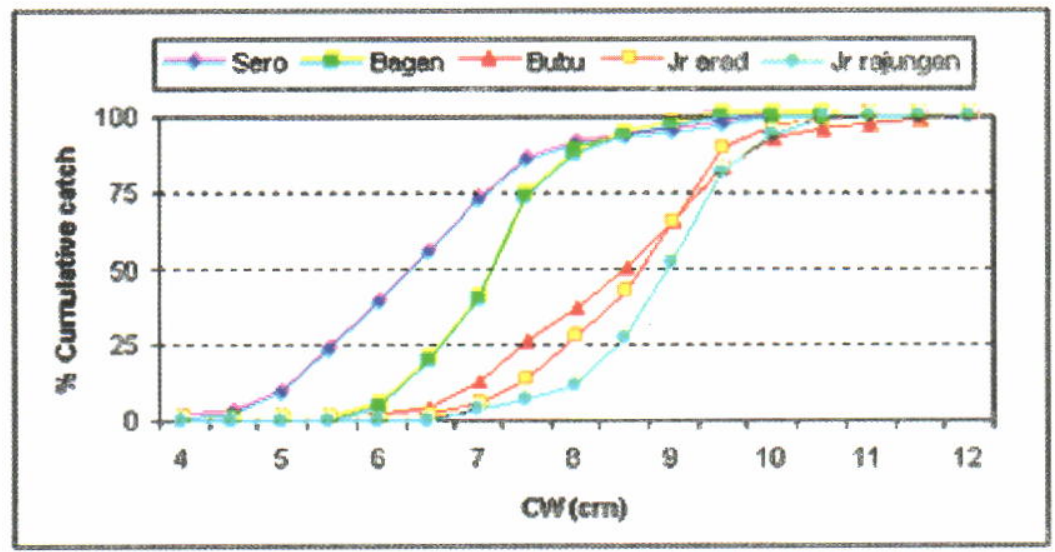

Gambar 4. Selektivitas rajungan pada alat tangkap sero, bagan, bubu lipat, jaring arad, dan jaring rajungan di perairan Teluk Jakarta.

Figure 4. Selectivity of swimming crab for guiding barrier trap, fixed lift net, collapsible trap, beach seine, and crab gillnet in Jakarta Bay. 
Tabel 4. Hubungan antara panjang karapas dan lebar karapas rajungan

Table 4. Relationships between carapace lengths and carapace width of swimming crab

\begin{tabular}{lcccccc}
\hline \multirow{2}{*}{$\begin{array}{c}\text { Jenis alat tangkap/ } \\
\text { Fishing gear }\end{array}$} & $\begin{array}{c}\text { Hubungan Panjang } \\
\text { dan Lebar karapaks/ } \\
\text { CW-CL relationships }\end{array}$ & \multicolumn{2}{c}{$\begin{array}{c}\text { Hubungan Panjang dan Lebar/ } \\
\text { CW-Weight relatonships }\end{array}$} & No. sample \\
\cline { 2 - 6 } & & $\mathrm{r}^{2}$ & $\mathrm{a}$ & $\mathrm{b}$ & $\mathrm{r}^{2}$ & \\
\hline Sero & $\mathrm{CW}=0,4446 \mathrm{CL}+0,1892$ & 0,9269 & 0,0933 & 2,7831 & 0,9427 & 157 \\
Bagan & $\mathrm{CW}=0,4314 \mathrm{CL}+0,3475$ & 0,8385 & 0,169 & 2,4923 & 0,8298 & 233 \\
Bubu rajungan & $\mathrm{CW}=0,4718 \mathrm{CL}+0,1843$ & 0,8312 & 0,145 & 2,6209 & 0,853 & 90 \\
\hline
\end{tabular}

Pertambahan panjang dan lebar karapas akan saling mempengaruhi antara satu sama lain. Pertambahan lebar karapas rajungan $1 \mathrm{~cm}$ akan diikuti dengan pertambahan panjang karapas 0,$64 ; 0,77$; dan $0,65 \mathrm{~cm}$. Pertumbuhan sangat dipengaruhi oleh ketersedian pakan pada lokasi di mana pakan sangat terbatas atau tidak tersedia karena perubahan ligkungan, maka rajungan akan mengalami pertumbuan yang lambat atau negatif.

\section{KESIMPULAN DAN SARAN}

1. Rajungan yang tertangkap oleh nelayan di perairan Teluk Jakarta sebagian besar merupakan rajungan kecil dan muda. Rajungan yang tertangkap mempunyai lebar karapas 4,16-11,9 cm dan bobot antara 5,1-113 g.

2. Rajungan kecil tertangkap dengan sero dan bagan, dengan bubu dan jaring rajungan ukuran rajungan semakin besar. Pertambahan ukuran rajungan yang tertangkap seiring dengan perubahan ekosistem dari ka: vasan estuaria sebagai habitat rajungan kecil ke ekosistem laut yang merupakan habitat rajungan dewasa.

3. Rajungan pertama kali tertangkap $\left(\mathrm{LC}_{50 \%}\right)$ dengan sero, bagan, bubu, jaring rajungan, dan jaring arad masing-masing berukuran lebar karapas 6,$3 ; 7,3$; 8,$54 ; 8,96$; dan $8,69 \mathrm{~cm}$.

4. Seks rasio jantan dan betina tidak sama pada alat tangkap yang digunakan. Pada sero dan jaring arad jumlah rajungan jantan lebih banyak dibandingkan betina, pada bagan, bubu, dan jaring rajungan jumlah jantan lebih sedikit dibandingkan betina. Hal tersebut diduga karena migrasi rajungan betina untuk memijah, adanya perbedaan lokasi penangkapan dan alat tangkap yang digunakan.

5. Studi morfometrik ikan memperlihatkan adanya hubungan antara lebar karapas (CW) dan panjang karapas (CL). Hubungan antara lebar karapas dan panjang karapas pada sero, bagan, dan bubu rajungan mengikuti persamaan
$C W=0,4446 C L+0,1892\left(r=0,9^{3}\right)$, $C W=0,4314 C L+0,3475 \quad(r=0,84) \quad$ dan $C W=0,4718 \mathrm{CL}+0,1843(r=0,83)$. Pertambahan lebar karapas rajungan $1 \mathrm{~cm}$ akan diikuti dengan pertambahan panjang karapas 0,$64 ; 0,77$; dan 0,65 $\mathrm{cm}$.

6. Secara teori, penangkapan rajungan yang muda oleh nelayan bagan dan sero dalam jumlah besar akan sangat bepengaruh terhadap kelestarian sumber daya rajungan. Untuk kepentingan pengelolaan sumber daya rajungan, maka sebaiknya tidak dilakukan penangkapan rajungan muda di kawasan pantai Teluk Jakarta. Dengan melarang penangkapan rajungan kecil yang sering tertangkap dengan sero dan bagan akan memberi peluang pada rajungan untuk dapat tumbuh menjadi lebih besar sebelum ditangkap dan mempunyai peluang yang lebih besar untuk memberikan nilai jual yang lebih tinggi.

\section{PERSANTUNAN}

Tulisan ini merupakan kontribusi dari kegiatan riset identifikasi kondisi sumber daya, lingkungan, dan kesesuaian lahan perikanan di Teluk Jakarta, T. A. 2006, di Balai Riset Perikanan Laut, Muara BaruJakarta.

\section{DAFTAR PUSTAKA}

Anonimus. 2007. Statistik Perikanan Tangkap Tahun 2007. Departemen Kelautan dan Perikanan. Direktorat Jenderal Perikanan Tangkap. Jakarta.

Bellchambers, L. M. \& S. de Lestang. 2005. Selectivity of different gear types for sampling the blue swimmer crab, Portunus pelagicus L. Fisheries Research. 73: p. 21-27.

Kailola, P. J., M. J. Williams, P. C. Stewart, R. E. Riechelt, A. McNee, \& C. Grieve. (eds). 1993. Australian Fisheries Resources Bureau off Resources Sciences. Canberra. 422 pp. 
Kangas, M. I. 2000. Synopsis of the biology and exploitation of the biue swimmer crab, Portunus pelagicus Linnaeus, in Western Australia. Fisheries Research Report No. 121 Fisheries Research Division. Marine Research Laboratories. North Beach Western Australia 25 pp. Website: http://www.wa.gov.au/westfish/res diakses pada tanggal 14 Maret 2009.

Karsono, W., S. T. Hartati, \& A. Priatna. 2006. Sebaran, intensitas, produktivitas, komposisi, dan kondisi biologi ikan hasil tangkapan alat tangkap pasif menetap di Teluk Jakarta. Prosiding Seminar Nasional Ikan IV. Jatiluhur, 29-30 Agustus 2006.

King, M. 1995. Fisheries Biology, Assessment, and Management. Fishing News Books. Hongkong. Fifth edition.

Potter, I. C., P. J. Chrystal, \& N. R. Loneragan. 1983. The biology of the blue manna crab $P$. pelagicus in an Australian estuary. Marine Biology. 78: 7585.

Potter, M. A., W. D. Sumpton, \& G. S. Smith. 1991. Movement, fishing sector impact, and factors affecting the recapture rate of tagged sand crabs, Portunus pelagicus (L.) in Moreton Bay, Queensland. Australian journal of Marine and Freshwater Research. 42: p. 751-760.

Potter, I. C., S. de Lestang, \& G. C. Young. 1998. Influence of the dawesville Channel on the recruitment, distribution, and emigration of crustaceans and fish in the Peel-Harvey Estuary. FRDC Final Report. Project 95/042. $61 \mathrm{pp}$.

Sukumaran, K. K. \& B. Neelakantan. 1996. Mortality and stock assessment of two marine portunid crabs, Portunus (Portunus) sanguinolentus (Herbst) and Portunus (Portunus) pelagicus (Linnaeus) along the south-west coast of India. Indian Journal of Fisheries. 43: 225-240.

Sparre, P. \& S. C. Venema. 1992. Introduction to tropical fish stock assessment. Part 1. Manual. FAO Fish. Tech. Pap. (306/1) Rev. 1: 376 pp.

Sumpton, W. D., M. A. Potter, \& G. S. Smith. 1994. Reproduction and growth of the commercial sand crab, P. pelagicus L. in Moretn Bay. Quensland. Asian Fisheries Sociey, Manila, Phillipinnes. Asian Fisheries Science. 7: 103-113. 
